Article

\title{
Examining Water Area Changes Accompanying Dam Construction in the Madeira River in the Brazilian Amazon
}

\author{
Dengqiu Li ${ }^{1,2}$, Dengsheng $\mathrm{Lu}^{1,2, * \mathbb{C}}$, Emilio Moran ${ }^{3} \mathbb{C}$ and Ramon Felipe Bicudo da Silva ${ }^{4,5}$ \\ 1 State Key Laboratory for Subtropical Mountain Ecology of the Ministry of Science and Technology and \\ Fujian Province, Fujian Normal University, Fuzhou 350007, China; lidengqiu001@163.com \\ 2 School of Geographical Sciences, Fujian Normal University, Fuzhou 350007, China \\ 3 Center for Global Change and Earth Observations, Michigan State University, East Lansing, MI 48823, USA; \\ moranef@msu.edu \\ 4 Center for Systems Integration and Sustainability, Department of Fisheries and Wildlife, \\ Michigan State University, East Lansing, MI 48823, USA; ramonbicudo@gmail.com \\ 5 Center for Environmental Studies and Research, State University of Campinas, Campinas 13083-867, Brazil \\ * Correspondence: ludengsheng@fjnu.edu.cn
}

Received: 26 May 2020; Accepted: 2 July 2020; Published: 6 July 2020

check for updates

\begin{abstract}
Two recently constructed run-of-the-river dams (Santo Antônio and Jirau), along the Madeira River in Brazil, have been controversial due to their large unquantified impacts on (1) land use and land cover (LULC) and (2) on the area that would be flooded. Based on annual LULC data from 1985 to 2017, this study integrated intensity analysis and difference components methods to analyze the impacts of the two dams on the annual flooded area in upstream, midstream, and downstream regions of the Madeira River. The dam construction significantly influenced LULC change intensity in the upstream and midstream regions since 2011 and 2010, respectively. An increase of $18.5 \%$ of the newly flooded area $\left(462.58 \mathrm{~km}^{2}\right)$ in the post-dam construction period was observed. The water gross gain intensity was active during 2011-2017 and 2011-2014 in upstream and midstream, respectively. The dominant difference components of water change were exchanged in the pre-dam period and became quantity in the post-dam period for both upstream and midstream regions. Forest was the major land category replaced by water; however, the highest gain intensities occurred in other non-vegetated areas in upstream and midstream. This study provided a useful approach for characterizing impacts of dam construction on water area change.
\end{abstract}

Keywords: Santo Antônio and Jirau dams; intensity analysis; difference components; land use and land cover; water area change

\section{Introduction}

The Amazonian basin is the vastest and complex river network on Earth [1]. The river system has great capacity and potential for power generation with possible great economic benefits. At the same time, its natural system supports rich biodiversity with a huge ecological value [2]. Brazil has long embarked on the construction of hydroelectric dams in the Amazon region [3], attracting the attention of scholars, public, environmental protection personnel, and local residents to the associated environmental problems [4-7]. Quantifying the trends in water area change at different sections of the river is critical to accurately assess the impacts of dam construction and to build policies to protect the river's ecosystem services [8].

The Madeira River is the largest tributary of the Amazon River, with the largest catchment area, water volume, and sediment flow among its tributaries. Recently, the Madeira River's dams of 
Santo Antônio and Jirau attracted attention, given the unknown effects on the spatial redistribution of the water dynamics and in the seasonality of flooded areas, on land use and land cover (LULC), and to the permanent water area thereby created [2]. The dams, aimed for hydroelectric power generation, would significantly change the water levels upstream and downstream depending on their topographical characteristics and the size of the reservoirs [3]. Previous studies have observed that dams may trap large amounts of sediment, which is a major driver of water resources and land use and land cover changes (LULCC) within water basins [2,7]. This is particularly serious for the Madeira River, which accounts for about 50\% of the Amazon River's sediment. However, the influence of these dams on water resources has not been accurately quantified because their projects have been driven by political pressure and economic factors, and there has been a lack of thorough evaluation from professional and technical institutions $[4,5]$.

The potential impact of dam construction on water resources has been considered. The original plan of Brazil was to construct one mega-dam upstream of Porto Velho to take advantage of the Santo Antônio Falls. However, the final decision was to build two dams by dividing the upstream area of Santo Antônio Falls into two smaller reservoirs. The decision to change the original plan was intended to avoid flooding part of Bolivia [5]. Furthermore, the two dams adopted horizontal bulb turbines (the first in Brazil), given their potential to minimize impacts on the water level brought on by the dams [9]. Hence, the impacts of the construction of the two dams with horizontal bulb turbines on water area change were expected to be minimal if compared with the potential impacts of hydroelectric power plans with large reservoirs. However, due to the lack of accurate and in-depth research and analysis, the impacts of these two dams on water resources were controversial from the outset $[2,10]$. The project proponents and the press repeatedly stressed that the two dams would not cause water levels to exceed natural flood levels, while the public and people involved in dam preparation had doubts about this position [5]. Moreover, and until that time, little was known about the impacts of horizontal bulb turbines on water area change in the Amazon because most previous studies for planning the Madeira River dams were focused on vertical axis turbines [9,11]. The most sensitive areas to the effects (e.g., reservoir impoundments) of the dam construction should have been more clearly quantified to provide better guidance for riverside residents and local government [5].

Examining spatial patterns of water surface distribution and its dynamics is essential for water management and ecosystem function evaluation [12-14]. The effects of dam construction on water area change have been assessed in many large dams around the world. In South Asia, for example, six Upper Mekong basin mainstream dams and 71 Lower Mekong basin tributary dams decrease the river's annual flooded area by $6.6 \%$ on average [15]. The Three-Gorges dam in China has little impact on the lake inundation area across the Yangtze Plain [16], while Brazil's Belo Monte hydroelectric dam considerably increases water area upstream, but decreases water area in downstream [7]. The completion of the Manwan dam (China) in the Lancang River increased the water area from $9.70 \mathrm{~km}^{2}$ in 1988 to $21.99 \mathrm{~km}^{2}$ in 2014 [17]. Dam construction might also change the inundation frequency in riparian wetland areas, given the flow modification effects [18]. Al-Madhhachi et al. [19] predicted that the impacts for the upstream section of the Ilisu dam (Turkey) could reduce by about one-fifth of the total area compared with the originally designed Mosul dam watershed area. The increased water shortage caused by dam construction in many places has resulted in conflicts between upstream and downstream communities [20]. Quantification of the water area change in different parts and distances has become more and more important for better understanding the effects of dam construction on the distribution and dynamics of water resources.

LULCC is one of the most sensitive and commonly used indicators, reflecting the changes in the natural environment and the influence of human activities [21]. LULCC has noticeable effects on water resource changes, including streamflow, water level, and quality [22]. It is one of the important factors that should be considered to analyze the drivers of water resource dynamics in various algorithms and simulation models $[14,23]$. Dam construction usually changes the land cover patterns in the river system, including submerged land, loss of natural ecosystems, watershed fragmentation, and degradation 
of adjacent land resources $[17,24]$. LULCC may offset or exacerbate hydropower-induced flow alteration $[14,25,26]$. Revealing the patterns and processes of LULCC is critical for investigating the complex interactions between human activities and environmental changes $[17,27]$. The time series of remotely sensed data and products have fostered LULCC investigations worldwide [28,29]. It can regularly monitor water surface area without the need for flow records, which are absent for many rivers [30,31]. A proper representation of water changes over long periods (before and after dam construction) is the foundation for a deep understanding of how changes in water area are related to dam construction. However, using traditional transfer matrix analysis of LULC is difficult to conclude whether the change patterns are more or less intensive compared with a random or uniform change $[7,32,33]$. Aldwaik and Pontius developed the intensity analysis method to characterize various forms of LULCC, including the areas and intensities of gross change, gains, losses, and transitions among different categories [32]. This method has been used to examine the LULC processes in many regions, reaching results with high confidence levels [34-38]. To supplement intensity analysis and to reflect changes in the components, the gross difference in the LULC matrix has been further dissected into quantity, exchange, and shift by difference components [39]. Previous studies have demonstrated that the integration of intensity analysis with difference components improves the capacity for understanding and interpreting LULC [40]. This method was used to evaluate the effectiveness of cropland requisition-compensation balance policy in maintaining the total cropland area in China [41] and to interpret the LULC during the period of 2000-2010 based on the GlobeLand30 maps of Asia [42]. Previous studies have mainly focused on LULC of two or multiple time points [38-41], but have not been used to examine the response of a specific land category change process (such as water) to human activities with annual LULC data.

This research aimed to use intensity analysis and difference components to evaluate changes in water surface area and examine the impacts of dam constructions on the change patterns. Specifically, a 33-year LULC dataset was used to quantify the areas, intensities, and components of annual change for LULC and water area from 1985 to 2017 in the Madeira River, the Brazilian Amazon, to answer the following questions: (1) How did the dam constructions affect the LULC process in upstream, midstream, and downstream regions? (2) How did the dam constructions influence changes in water surface area dynamics (dormant or active) and change components? (3) Did the dam constructions significantly change the pattern of water transition size and intensity? (4) Did the distance from dam influence water area gain and loss intensities? This study might provide a new perspective for understanding the impacts of Jirau and Santo Antônio dams on LULC and water area dynamics and for guiding future dam construction plans and management.

\section{Study Area}

The Madeira River, which runs a distance of $3352 \mathrm{~km}$ from Bolivia to Brazil, is one of the major contributors to the Amazon River in Brazil, and its watershed (i.e., the Madeira River watershed) represents $23 \%$ of the Amazon basin [43]. The river flows northward, forming the border between Bolivia and Brazil for approximately $100 \mathrm{~km}$. After receiving the Abuná River, the Madeira River flows northeastward in Brazil through Rondônia and Amazonas states to its junction with the Amazon River. Beginning in the Andean regions of Peru and Bolivia, its altitudinal gradient variation from the Andes towards the Amazon flood plains gives the Madeira River and its watershed's many tributaries high hydroelectric potential. With two large hydroelectric power plants (Jirau (construction was completed in 2012) and Santo Antônio (construction was completed in 2011) $[4,6]$ ) (Figure 1), the watershed has the potential to add more dams for hydroelectric power generation $[5,10]$. The study area was determined based on the locations of the two dams in Rondônia state. The region has a humid tropical climate with annual precipitation around 1900-2200 mm [44]. The Madeira's mean annual discharge is about $18,500 \mathrm{~m}^{3} / \mathrm{s}$ but can reach $45,000 \mathrm{~m}^{3} / \mathrm{s}$ during strong flood periods [45]. In an annual cycle, there are four hydrological periods: low water (August to November), flood (December to January), high water (February to May), and ebb (June to July) [43]. 

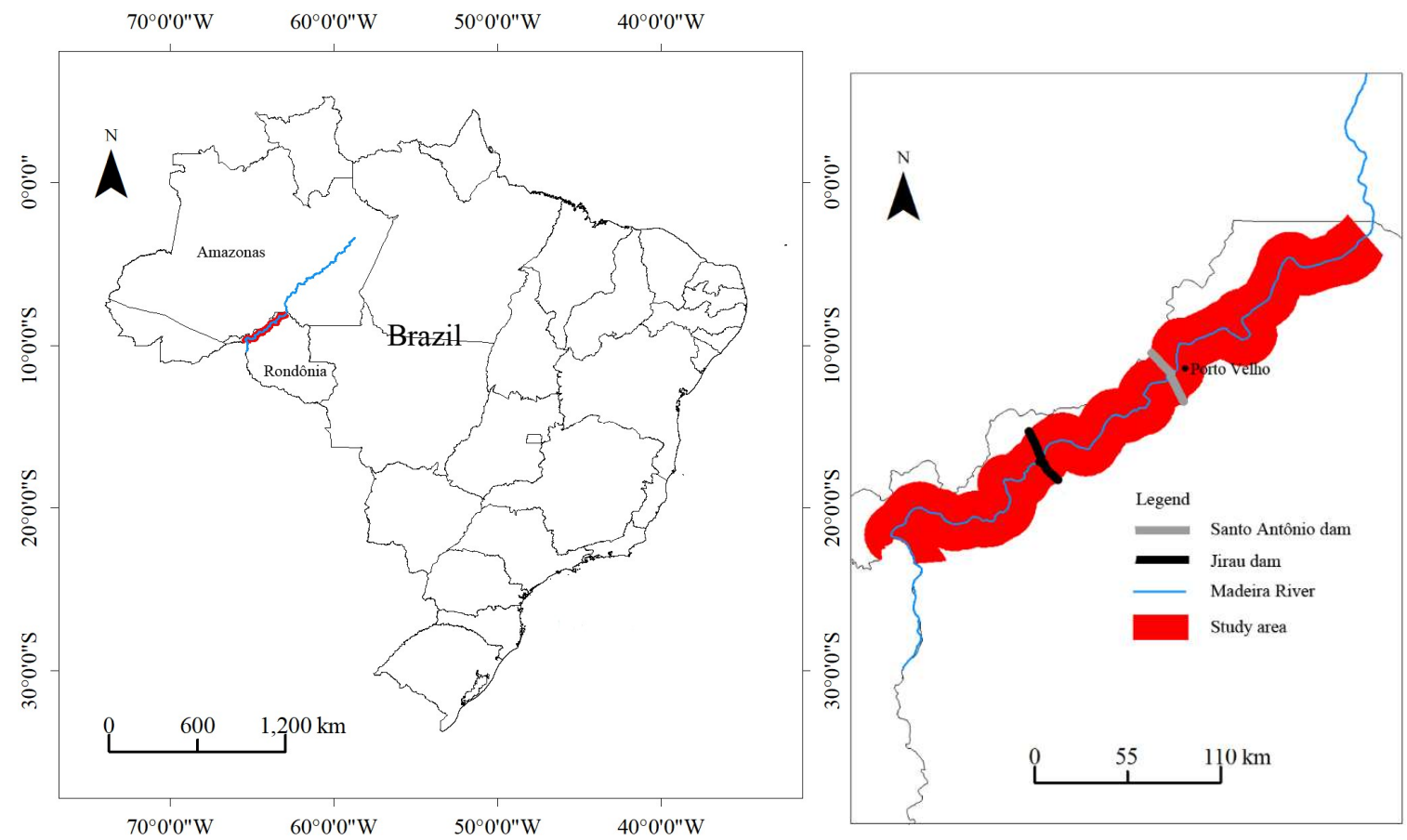

Figure 1. Location of the study area and two dams in the Madeira River in Brazil.

The major city in the Brazilian part of the Madeira watershed is Porto Velho (capital of Rondônia state), with a population of 369,259 (Instituto Brasileiro de Geografia e Estatistica (IBGE), 2010). The Jirau dam is about $136 \mathrm{~km}$ from Porto Velho (upstream), while Santo Antônio is located only $7 \mathrm{~km}$ from the city [9] (Figure 1). The Jirau and Santo Antônio hydroelectric power plants are two run-of-the-river dams and, therefore, without the need for large water reservoirs [9,43,46]. However, they have been considered mega-dams as their power generation amount to $3750 \mathrm{MW}$ and $3150 \mathrm{MW}$, respectively [2]. The run-of-the-river dams—-the Jirau dam and Santo Antônio dam-have the flooded area of $258 \mathrm{~km}^{2}$ and $271 \mathrm{~km}^{2}$, respectively [6,45]. Table 1 provides some key characteristics of the two dams. Mega constructions in Amazon biome with high potential to environmental and social impacts require previous and in-depth contingency plans and socio-environmental impact studies [10,43], but recommendations are rarely enforced.

Table 1. Key characteristics of the Jirau dam and Santo Antônio dam.

\begin{tabular}{ccc}
\hline Information & Jirau dam & Santo Antônio dam \\
\hline Power generation capacity $(\mathrm{MW})$ & 3750 & 3150 \\
Dam height $(\mathrm{m})$ & 63 & 13.9 \\
Dam length $(\mathrm{m})$ & 980 & 3100 \\
Number of bulb turbines & 50 & 44 \\
Water levels $(\mathrm{m})$ & $82.5-90$ & $56.3-71.3$ \\
Reservoir area range $\left(\mathrm{km}^{2}\right)$ & $21-207.7$ & $164-271$ \\
The maximum of possible storage volumes of & 2747 & 2710 \\
the reservoirs $\left(\times 10^{6} \mathrm{~m}^{3}\right)$ & 258 & 271 \\
Maximum reservoir surface area $\left(\mathrm{km}^{2}\right)[6,45]$ & 2012 & 2011 \\
Dam completion year [6] &
\end{tabular}

Note: The information was from https://ejatlas.org/print/jirau-and-santo-antonio-dams-on-madeira-river-brazil; https://www.hydropower.org/case-studies/brazil-jirau (acquired on 26 June 2020). 


\section{Materials and Methods}

\subsection{Collection of Annual Land Use and Land Cover Data}

MapBiomas provides annual LULC maps for entire Brazil from 1985 to the present (MapBiomas Project, Collection Version 3.0 of the Annual Land Use Land Cover Maps of Brazil, accessed on July-2019 through the link: https://mapbiomas.org). The MapBiomas united the experts from different fields (ecology, remote sensing, geographic information science, computing science, etc.) and relied on the Google Earth Engine platform and automated classifiers to generate Brazil's annual LULC. In this study, the annual LULC data were used from Collection 3 products covering the period 1985-2017 (published in August 2018, Figure 2a-c). The detailed generation process of LULC data is described on the website and summarized briefly here. Firstly, Landsat images were collected with low cloudy coverage and high spectral contrast among LULC categories from a defined period to generate annual mosaics. Secondly, various forms of variables from Landsat bands (105 metrics, including each of the 7 spectral bands, as well as for the calculated spectral fractions and indices) were created to run the random forest classifier. The classification was based on training samples acquired from temporally stable LULC categories, which were generated in the previous products of Collection 2.3-reference maps and manual sampling. Then, the accuracy assessment analysis was conducted in the current map Collection (i.e., Collection v.3.0) [47]. Table 2 provides the definition of the LULC classification system and area occupied by each category in three years $(1985,2011$, and 2017).

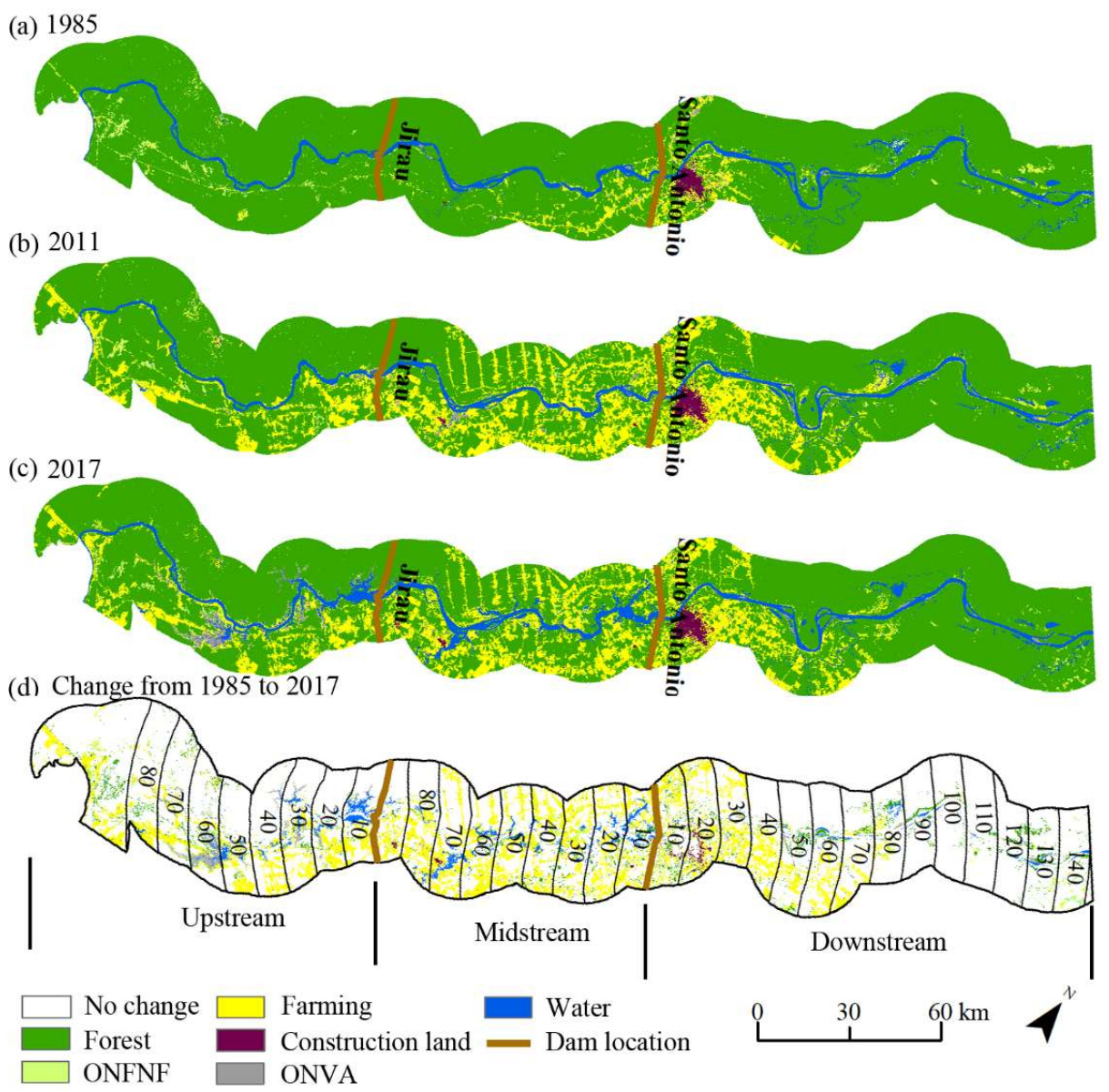

Figure 2. Maps of land cover categories in (a) 1985; (b) 2011; (c) 2017; (d) Change direction from 1985 to 2017 and buffer zones for two dams in the study area (Note: ONFNF: other non-forest natural formation, ONVA: other non-vegetated areas. The numbers in (d) indicate the distance from buffer zones to the dam. The number in upstream shows the distance to the Jirau dam. The number in midstream and downstream is the distance to Santo Antônio dam). 
Table 2. Definitions of land use and land cover categories and a summary of statistical area for each category in this study area in 1985, 2011, and 2017.

\begin{tabular}{|c|c|c|c|c|}
\hline \multirow{2}{*}{$\begin{array}{l}\text { Land Cover } \\
\text { Category }\end{array}$} & \multirow{2}{*}{ Definition } & \multicolumn{3}{|c|}{ Area $\left(\mathrm{km}^{2}\right)$} \\
\hline & & 1985 & 2011 & 2017 \\
\hline Forest & Natural forest and plantations & $11,283.9$ & 9533.4 & 9299 \\
\hline $\begin{array}{c}\text { Other non-forest } \\
\text { natural formation } \\
\text { (ONFNF) }\end{array}$ & $\begin{array}{l}\text { In MapBiomas, wetland, grassland } \\
\text { formation, salt flat, and other non-forest } \\
\text { natural formation (ONFNF) are grouped to } \\
\text { non-forest natural formation. In this study } \\
\text { area, only ONFNF existed }\end{array}$ & 213.7 & 131.1 & 150.3 \\
\hline Farming & $\begin{array}{c}\text { Pasture, agriculture, and mosaic of } \\
\text { agriculture and pasture }\end{array}$ & 419 & 2223.5 & 2134.5 \\
\hline Construction land & $\begin{array}{l}\text { Beach and dune, urban infrastructure, } \\
\text { rocky outcrop, and mining }\end{array}$ & 71.7 & 89.5 & 94.8 \\
\hline $\begin{array}{l}\text { Other } \\
\text { non-vegetated area } \\
\text { (ONVA) }\end{array}$ & $\begin{array}{l}\text { Land cover with exposed soils or naturally } \\
\text { exposed rocks without soil cover }\end{array}$ & 48.3 & 89.6 & 171.8 \\
\hline Water & River, lake, and aquaculture & 674.4 & 643.9 & 860.6 \\
\hline
\end{tabular}

\subsection{Examining the Impacts of Dam Construction on Land Use and Land Cover Change}

Cumulative sum (CUSUM) was utilized to reveal the water area net change from 1985 to 2017. The newly flooded area was defined as the area that had never been water before the dam was completed and was covered by water at least once after the dam was completed. Difference components and intensity analysis were adopted to further analyze LULC and processes of water area change in two steps: separated LULC and water change (the difference between two adjacent years) into quantity, exchange and shift based on difference components method [39], and computed the component's intensity of LULC and water change following intensity analysis theory $[32,40,48]$. The gain and loss intensities and transition intensity were calculated for a water change. In addition to the difference components and intensity analysis approaches for upstream, midstream, and downstream, buffer analysis was also used to examine the impacts of dam construction on water area change according to different distances from the dam sites.

\subsubsection{Difference Components}

The quantity component of each category is the absolute difference between the increase of gross area from other categories and the decrease of the gross area to other categories. The exchange component represents the area exchanged between two categories but without a change in the area of both (e.g., category $i$ changes to category $j$ in some locations, while category $j$ changes to category $i$ in other locations during the same period). The shift component is the difference that belongs to neither the quantity component nor the exchange component. Equations (1)-(4) are change component calculations of LULCC at category level:

Equation (1) calculates the total difference by summing the area changed to category $j$ from other categories (gross gain) and the area changed to other categories from category $j$ (gross loss).

$$
d_{j}=\operatorname{Gain}_{j}+\text { Loss }_{j}=\left[\sum_{i=1}^{J}\left(C_{i j}+C_{j i}\right)\right]-2 C_{j j}
$$

Equation (2) expresses the quantity component by calculating the absolute difference between gross gain and gross loss for category $j\left(q_{j}\right)$.

$$
q_{j}=\mid \text { Gain }_{j}-\text { Loss }_{j}|=| \sum_{i=1}^{J}\left(C_{i j}-C_{j i}\right) \mid
$$


Equation (3) indicates the exchange component by calculating the area that changed to other categories from $j$ and with the same area changed to $j$ from other categories for category $j(i \neq j)$.

$$
\left.e_{j}=2\left\{\left[\sum_{i=1}^{J} \operatorname{Min}_{\left(\text {Transition }_{i j}, \text { Transition }_{j i}\right)}\right)\right]-\text { Persistence }_{j}\right\}=2\left\{\left[\sum_{i=1}^{J} \operatorname{Min}\left(C_{i j}, C_{j i}\right)\right]-C_{j j}\right\}
$$

Equation (4) gives the shift component by subtracting the areas of quantity and exchange components from the total difference area $\left(d_{j}\right)$ for category $j$.

$$
s_{j}=d_{j}-q_{j}-e_{j}
$$

where lowercases $i$ and $j$ represent LULC categories, and $J$ is the total number of LULC categories, which were 6 in this study. $C_{i j}$ is the area changed from category $i$ to category $j$. In this study, Equations (1)-(4) were used to calculate change components for all 6 categories, but this study only focused on water. The $q_{j}$ reflects the net changed area of category $j$, but the exchange $\left(e_{j}\right)$ and shift $\left(s_{j}\right)$ components do not change the area of category $j$.

Equation (5) was used to compute overall difference size $(D)$ and overall change component sizes ( $Q$ (overall quantity change), $E$ (overall exchange change), $S$ (overall shift change)) by summing all categories. The results of Equation (5) were used to evaluate the impacts of the dam constructions on change components of all categories (i.e., LULC).

$$
X=\sum_{j=1}^{J} x_{j} / 2
$$

where $X$ equals $D, Q, E$, and $S ; x$ equals $d, q, e$, and $s$, respectively.

\subsubsection{Intensity Analysis}

The intensity analysis method analyzes LULC at the interval, category, and transition levels. These three levels explore very fine detail in the patterns of LULC $[36,48]$. The interval level can be used to examine the change dynamics of all LULC categories as a whole. Category level compares observed gain and loss intensities of each category with the uniform change intensity based on LULCC in every time interval. Transition level analysis shows the intensity of category $i$ changing to category $j$ compared with the uniform transition intensity. Due to the disproportionate distribution of area within the 6 categories (Table 2), water gain size from other categories was calculated to realize the water-related LULC at transition level, but not compared with uniform transition intensity.

Equation (6) shows the annual change intensity $U_{t}$ for a time interval $\left[Y_{t}, Y_{t+1}\right]$. It can be compared with the uniform annual change $\bar{U}$ of the study period $\left[Y_{1}, Y_{T}\right]$. If $U<\bar{U}$, then the change of this time interval is slow. If $U>\bar{U}$, then the change is fast. The time interval refers to a year to year change $\left[Y_{t}, Y_{t+1}\right]$, and when the interval is more than two years in a temporal extent of our statement $\left[Y_{t}, Y_{t+n}\right]$ $(n>=2)$, it represents the year to year intervals $\left[Y_{t}, Y_{t+1}\right],\left[Y_{t+1}, Y_{t+2}\right], \ldots,\left[Y_{t+n-1}, Y_{t+n}\right]$.

$$
U=\sum_{j=1}^{J}\left\{\left(\sum_{i=1}^{J} C_{i j}\right)-C_{j j}\right\} / \sum_{j=1}^{J} \sum_{i=1}^{J} C_{i j}=D / \sum_{j=1}^{J} \sum_{i=1}^{J} C_{i j}
$$

Equation (7) was used to compute the three overall change component intensities ( $Q^{\prime}$ (overall quantity change intensity), $E^{\prime}$ (overall exchange change intensity), and $S^{\prime}$ (overall shift change intensity)), with $d$ equals $D$ and $x$ equals $Q, E$, and $S$, respectively, at the interval level. Equation (7) was also used to compute the three change component intensities $\left(q^{\prime}, e^{\prime}\right.$, and $\left.s^{\prime}\right)$ for each category $j$ (here only focused on water) by taking the size of the component ( $x$ equals $q, e$, and $s$ ) divided by the total changed area 
(d). This study presented LULCC dynamics with a focus on the analysis of water dynamics at category and transition levels.

$$
x^{\prime}=100 x / d
$$

The loss intensity is the ratio of the lost area to the initial area for category $i$ in each interval (Equation (8)).

$$
l^{\prime}=\text { Loss }_{i} /\left(\text { Loss }_{i}+\text { Persistence }_{i}\right)=\left\{\left(\sum_{j=1}^{J} C_{i j}\right)-C_{i i}\right\} / \sum_{j=1}^{J} C_{i j}
$$

Equation (9) calculates the gain intensity of category $j$ as the ratio of gain area to the area of category $j$ at the final time in each interval. If $l^{\prime}\left(g^{\prime}\right)<U$, then $l^{\prime}\left(g^{\prime}\right)$ is considered dormant, meaning this category has experienced lower intensive loss (gain) than the mean level across the spatial extent. If $l^{\prime}\left(g^{\prime}\right)>U$, then $l^{\prime}\left(g^{\prime}\right)$ is considered active, indicating that the loss (gain) of the category $j$ is more intensive than the mean level across the spatial extent.

$$
\mathrm{g}^{\prime}=\text { Gain }_{j} /\left(\text { Gain }_{j}+\text { Persistence }_{j}\right)=\left\{\left(\sum_{i=1}^{J} C_{i j}\right)-C_{j j}\right\} / \sum_{i=1}^{J} C_{i j}
$$

Equation (10) gives the transition intensity by computing the ratio of the area changed from category $i$ to $j$ by the initial area of category $i$.

$$
t^{\prime}=\text { Transition }_{i j} /\left(\text { Loss }_{i}+\text { Persistence }_{i}\right)=C_{i j} / \sum_{j=1}^{J} C_{i j}
$$

\subsubsection{Buffer Analysis}

Buffer zone analysis was adopted to identify the areas sensitive to the dams by checking the water area changes according to the distances from each dam. Buffer zones surrounding the river were created at $12 \mathrm{~km}$ on two sides. The buffer zones were divided into three parts-upstream, midstream, and downstream-according to the locations of the dams (Figure 2d). To examine the distance effects on water area change, we considered the two dams as the centers to set buffer zones at $10 \mathrm{~km}$ intervals. In the upstream region of the Jirau dam, there were 8 buffer zones. The midstream region was an upstream area of Santo Antônio dam and downstream of the Jirau dam, and the buffer zone was most overlap with each other when setting buffer zones based on each dam. Therefore, the downstream of the Jirau dam used the buffer zone of the Santo Antônio dam. There were 8 buffers for upstream and midstream and 14 buffer zones for downstream, respectively.

\section{Results}

\subsection{Impacts of Dam Construction on LULCC}

The dynamics of change component intensities in the three regions during 1985-2017 indicated that the construction of the two dams had different impacts on LULC processes (Figure 3). The uniform changes of all LULC categories in upstream, midstream, and downstream regions $(\bar{U})$ were $2.4 \%, 3.5 \%$, and $2.8 \%$, respectively, from 1985 to 2017. The LULC largely increased since 2011 (i.e., 2011-2012, 2012-2013, . . 2016-2017 intervals) with the maximum overall change ( $D$ in Equation (5)) between 2015 and 2016 in the upstream region (Figure 3a). The difference components (quantity, exchange, and shift) were not significantly changed after 2011 compared with the period before the dam constructions (Figure $3 \mathrm{~b}$ ). The largest proportion of exchange (85.9\% of overall change) occurred in 2008-2009. In the midstream region, the LULC change rates significantly increased from 2010 (i.e., 2010-2011, 2011-2012, $\ldots$, 2016-2017), with the maximum overall change between 2011 and 2012 (Figure 3c). The exchange component occurred at high proportions during 2006-2010 (i.e., 2006-2007, . . , 2009-2010), with an 
annual average of $74 \%$ and a peak of exchange (80.9\% of overall change) between 2008 and 2009 (Figure 3d). The proportion of quantity significantly increased during 2010-2012, with an average of $52.6 \%$. The interval behaviors of the downstream region showed different patterns compared to the observed results of the upstream and midstream regions. The intervals were fast before 1998, decelerated between 1998 and 2015, and accelerated from 2015 onwards (Figure 3e). The proportions of quantity, exchange, and shift did not significantly change during the study period (Figure 3f). The change intensities were lower in the upstream than downstream before 2011 but higher after 2011. This indicated that the construction of the dams had significantly impacted the LULCC process in the upstream.
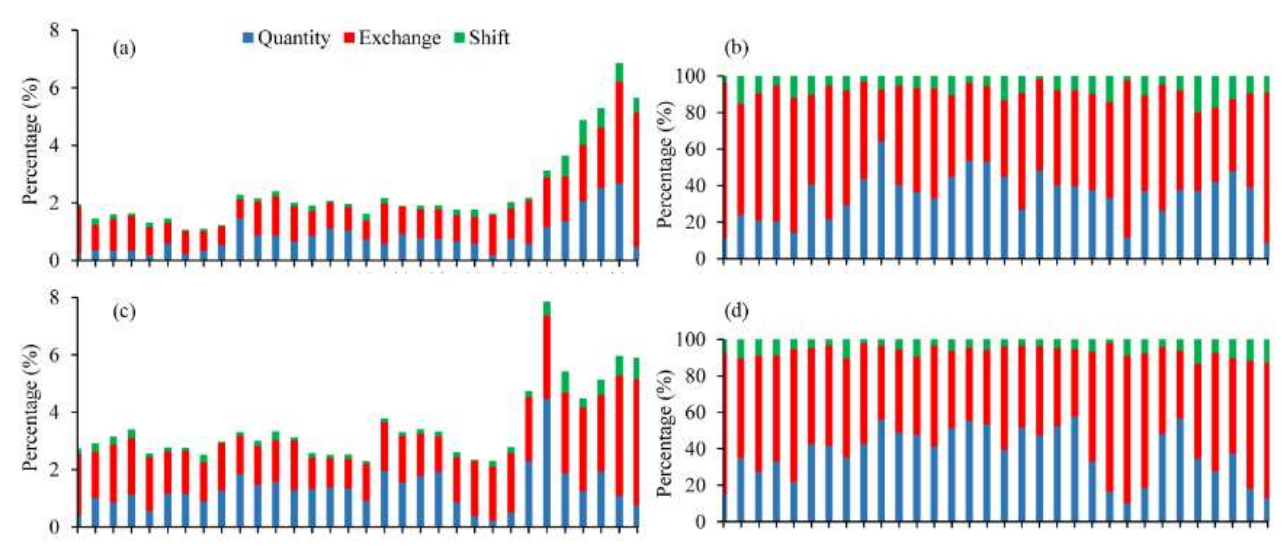

(d)
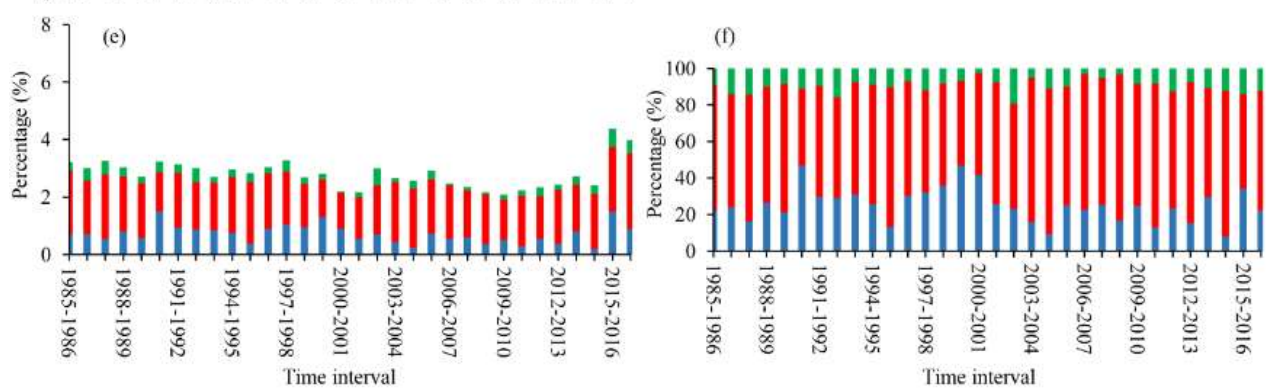

Figure 3. Change component percentage of the region (left panel) and percentage of change (right panel) in upstream $(\mathbf{a}, \mathbf{b})$, midstream $(\mathbf{c}, \mathbf{d})$, and downstream $(\mathbf{e}, \mathbf{f})$ regions at interval level for all land use and land cover (LULC) classes, respectively.

To examine the impacts of dam constructions on each LULC category in the upstream, midstream, and downstream, the statistics of gross loss, gross gain, and net changed area were calculated for pre-dam (1985-2011) and post-dam (2011-2017) periods, respectively (Tables S1-S3, Figure S1). Farming increased at the cost of forest reduction in the pre-dam period, but the pattern became more complicated in the post-dam period. The gross loss and gross gain of areas of each LULC category increased significantly in upstream (Table S1). Some categories (e.g., gross losses of the forest, other non-forest natural formation (ONFNF), and other non-vegetated areas (ONVA); gross gains of ONFNF, ONVA, and water) accounted for the largest proportions to the overall study area in the post-dam period (Table S2). The flooded area and ONFNF were the major drivers of deforestation (Table S3, Figure S1). The average annual increased area of farming changed from $17.95 \mathrm{~km}^{2}$ to $4.43 \mathrm{~km}^{2}$. In the midstream, the gross loss area of farming increased significantly, and the gross gain was similar between the two periods. A net reduction of the farming area was observed, which was mainly caused by large amounts of the flooded area, and returned to the forest in the post-dam period in midstream. A large area of farming land was inundated in 2011-2012, but no significant replacement of flooded farming land was observed (Figure S1). Forest showed an adverse change trend compared with that of farming, indicating the deforestation area decreased during 2011-2017 in midstream. Some farming land was recovered after a few years of dam completion in upstream and downstream (Figure S1b,d). 


\subsection{Impacts of Dam Construction on Water Area Change}

\subsubsection{Water Surface Area Change and Newly Flooded Area after Dam Construction}

Water surface area in upstream, midstream, and downstream regions increased and then decreased after the dam was completed in 2012 (Figure 4). A significant and steady increase since 2012 was observed in upstream, reaching a maximum increase in 2015. Midstream and downstream both reached the largest water surface area in 2014, a year of high, above average, rainfall. The midstream showed a sharp increase in 2012, significantly slowing down in 2013 and 2014. The water surface area was divided into three types (blue, green, and red areas in Figure 5a): (a) regions covered by water both at least once in 1985-2011 (pre-dam construction period) and 2012-2017 (post-dam construction period); (b) regions covered by water at least once in 1985-2011, but not covered in 2012-2017; (c) regions without water cover in 1985-2011, but covered at least once in 2012-2017. The water cover loss (situation b) was $230 \mathrm{~km}^{2}$ and mainly located in the downstream region $(69.8 \%)$. The newly flooded area (situation c) accounted for $462.6 \mathrm{~km}^{2}$ of the study area, which was equivalent to $48.2 \%$ of the water area in 1985-2011 (covered by water at least once within this period). The newly flooded area was mainly located upstream (44.4\%) and midstream (47.2\%) regions with an area of $205.6 \mathrm{~km}^{2}$ and $218.4 \mathrm{~km}^{2}$, respectively. A total of $18.5 \%$ of these newly flooded regions became permanent water areas throughout 2012-2017 and mainly located in midstream (Figure 5b).

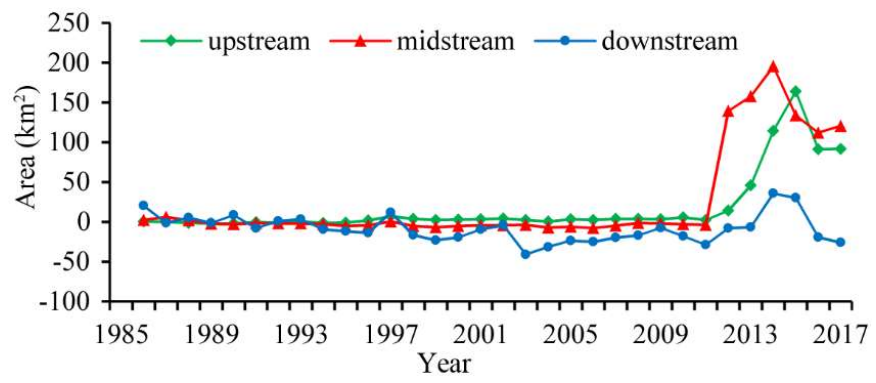

Figure 4. CUSUM (Cumulative Sum) of water area change in upstream, midstream, and downstream regions during 1985-2017.

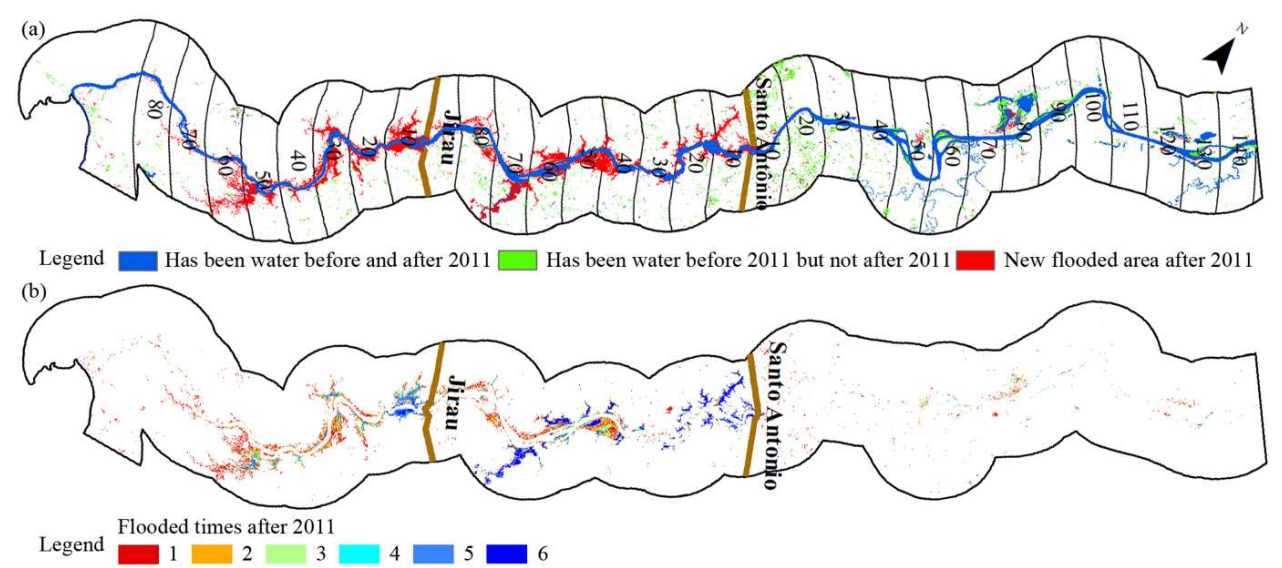

Figure 5. (a) Water surface area change before and after the completion of the dam; (b) Flooded times of these newly flooded areas during 2012-2017. The blue color in (a) means the pixels were covered by water both at least once in 1985-2011 (pre-dam construction period) and 2012-2017 (post-dam construction period). The green color in (a) means the pixels were covered by water at least once in 1985-2011 but were never covered by water in 2012-2017. The red color in (a) means the pixels were never covered by water in 1985-2011, but covered by water at least once in 2012-2017. 


\subsubsection{Dynamics of Water Change Components}

In the upstream region, the average percentage of quantity change was $30.6 \%$ during the period of 1985-2011 (before the dam was built) and increased to 60.6\% during the period of 2011-2017 (post-dam construction) (Figure 6a). While the exchange component showed conversely with the average percentage of exchange changed from $59.2 \%$ to $35.8 \%$. The components of water change showed a very different change pattern compared with that of LULC. The shift ratio was relatively low during all time intervals except in 2005-2006 and 2007-2008 (38.6\% and 44.9\%, respectively). In midstream region, quantity, exchange, and shift components accounted for $22.0 \%, 63.6 \%$, and $14.4 \%$, respectively, during 1985-2010, and they changed to 70.3\%, 29.7\%, and 0.1\% in 2010-2017 (Figure 6b). Before the dams' completion, exchange was the dominant water change component, while quantity was the major change component after the completion of the dams. The quantity change accounted for $98.7 \%$ of the overall water change in 2011-2012, indicating that the completion of dam construction significantly induced great net change of water area. In the downstream region, quantity change accounted for larger proportions in 2002-2003, 2013-2014, and 2015-2016 (69.2\%, 89.6\%, and 74.0\%, respectively) than in other periods (Figure $6 \mathrm{c}$ ). The exchange was the major change component in 2007-2008 and 2012-2013 as the proportions both exceeded 80\%.
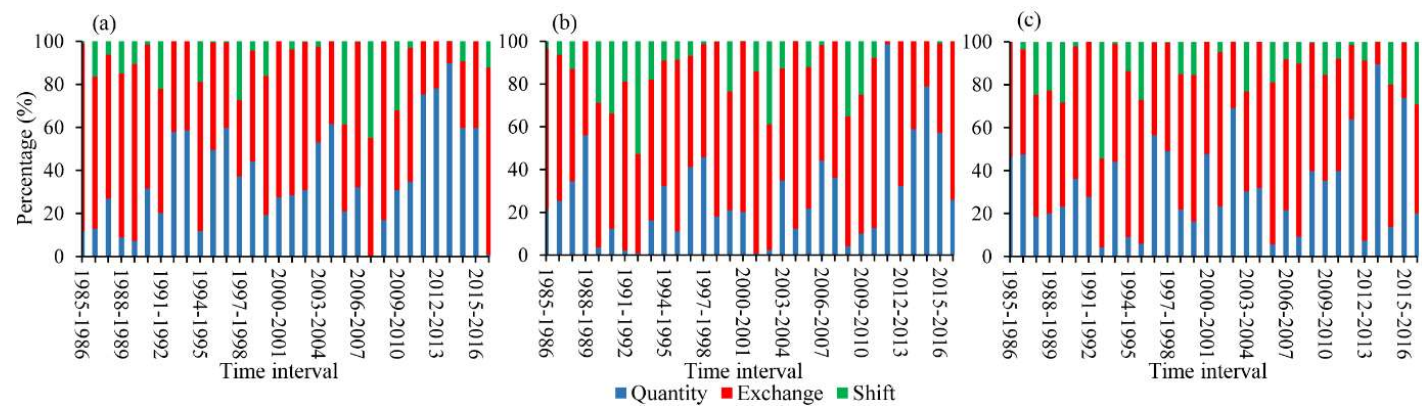

Figure 6. Percentage of water change components in (a) upstream, (b) midstream, and (c) downstream regions.

\subsubsection{Dynamics of Water Gross Gain and Gross Loss}

There were 12 intervals (for a total of 26 time intervals) with water gross gain greater than gross loss before 2011, and the water area net increased by $2.4 \mathrm{~km}^{2}$ during this period in the upstream region (Figure 7a). The water area had a net increase of $89.2 \mathrm{~km}^{2}$ during 2011-2017 as most intervals (within this period) showed larger gross gain than gross loss. Water gross gain and gross loss were 18 times at dormant state (less than uniform category intensity) before 2011, but the distribution was different (Figure 7b). It was observed that water gross gains were continuously active from 2011, while gross losses at a dormant state in 2011-2014 but active from 2014 onwards.

There were 13 intervals (for a total of 25 time intervals) showing gross gain less than gross loss before 2010, and the water area net reduced by $2.9 \mathrm{~km}^{2}$ in midstream region (Figure 7c). There were four intervals (total of seven time intervals) with a net gain, and the water area net increased by $123.3 \mathrm{~km}^{2}$ during 2010-2017. Water cover underwent the largest gross gain in 2011-2012 and the largest gross loss in 2014-2015. Water gross gains and gross losses were 17 times at a dormant state before 2010, with a persistently dormant state during 1998-2002 (Figure 7d). The high proportion of dormant state before the construction of the dam indicated that water change was less active than other categories. Water gross gain and loss showed greater instability after 2011. Although LULC accelerated between 2010 and 2011, both water gross gain and loss were found in the dormant state. This inconsistency indicated that the dam constructions led to significant changes in LULC, but the water area was less affected in 2011. Water gross gain was active during 2011-2014 but changed to dormant during 2014-2016. Water gross loss was non-stationary during 2011-2017, with active and dormant cycles occurring in alternation. 

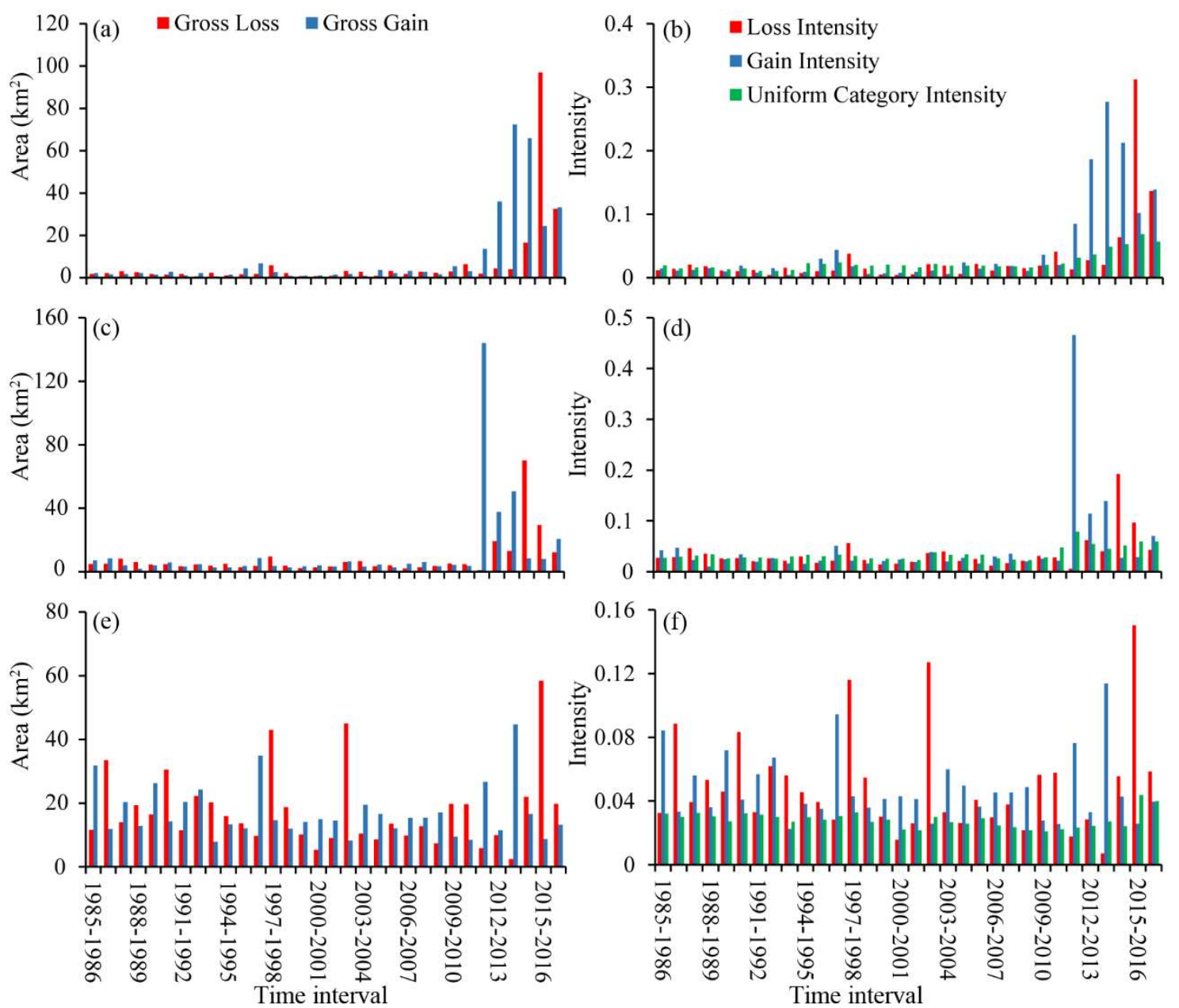

Figure 7. Water gross loss and gain size (left panel) and intensity (right panel) of upstream (a,b), midstream $(\mathbf{c}, \mathbf{d})$, and downstream $(\mathbf{e}, \mathbf{f})$ regions.

Although 17 intervals ( 32 in total) revealed net gain, the net water area was reduced by $25.9 \mathrm{~km}^{2}$ during 1985-2017 in the downstream region (net reduced by $29 \mathrm{~km}^{2}$ during 1985-2011, and net increased by $3.1 \mathrm{~km}^{2}$ during 2011-2017) (Figure 7e). The largest gross gain and gross loss occurred in 2013-2014 and 2015-2016, respectively. The intensity analysis showed that the dormant state of water gross gain and gross loss occurred 4 and 5 times between 1985 and 2017, respectively (Figure 7f). The low proportion of a dormant state indicated that water was more active than other land categories in the downstream region.

\subsubsection{Water Gain Size and Intensity from Other Categories}

The three regions showed different change trajectories in water gain size and intensity from other categories. Water gain was mainly from the forest, ONFNF, and farming with a percentage of $46.6 \%, 21.2 \%$, and $23.8 \%$ before 2011 (pre-dam period) in the upstream region (Figure 8a). Large gain intensities occurred on construction land and ONVA. After 2011 (post-dam period), water gain was mainly from forest and ONVA $(42.3 \%$ and $26.2 \%)$, and ONVA showed the largest gain intensity in 2011-2012. The water gain from the forest mainly occurred between 2013 and 2015 (Figure 8b). In the midstream region, the water gain was mainly from the forest, farming, and ONVA before 2011. Water gain was concentrated on forest and farming from 2011 to 2017 (Figure 8c). The contribution from ONVA to water significantly reduced compared with that of the upstream region. Gain intensity from ONVA was larger than other categories before 2011. The whole gain intensity significantly increased in 2011-2012, and the gain intensity of ONFNF showed an obvious increase compared with the period 
before the dam was constructed. The overall gain intensity decreased rapidly after 2014 (Figure 8d). In the downstream region, there was no significant difference between 1985-2011 and 2011-2017 for water gain patterns (Figure 8e). Water gain from forest accounted for 50.15\% in 1985-2017. ONVA and ONFNF showed strong gain intensity in most intervals (Figure 8f).
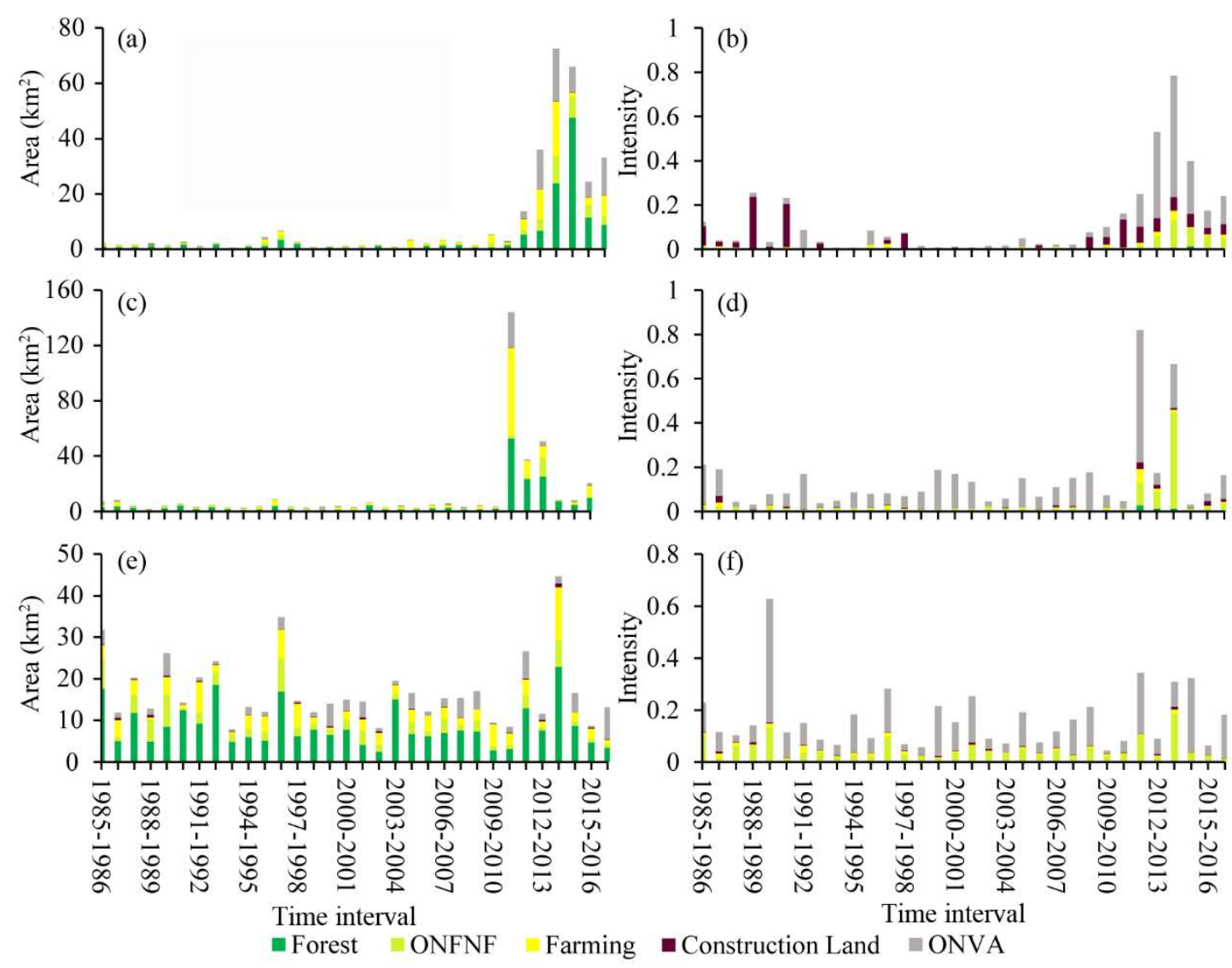

Figure 8. Water gross gain size (left panel) and intensity (right panel) in upstream (a,b), midstream $(\mathbf{c}, \mathbf{d})$, and downstream (e,f) regions in 1985-2017 (Note: ONFNF: other non-forest natural formation, ONVA: other non-vegetated areas).

\subsection{Characteristics of Water Area Change in Different Buffer Distances}

The largest water area increase occurred between 2012 and 2013, and the net gain started from 2011-2012 in the $10 \mathrm{~km}$ buffer zone of the upstream region (Figure 9a). The water area changes were not obvious in the $70 \mathrm{~km}$ and $80 \mathrm{~km}$ buffer zones. The largest net water gain was in 2013-2014, and the largest loss was in 2015-2016, both occurred in a $30 \mathrm{~km}$ buffer zone. According to loss intensity in the upstream region, the $60 \mathrm{~km}$ buffer zone presented water loss since 2013, and all buffer zones showed the largest water loss intensity in the 2015-2016 interval (Figure 9b). Gain intensity within the $10 \mathrm{~km}$ buffer zone increased significantly from 2011-2012 and reached maximum gain in 2013-2014 (Figure 9c). The 20, 30, 50, and $60 \mathrm{~km}$ buffer zones increased significantly in 2013-2014. Thus, the response of water area change to the Jirau dam construction in the upstream region could be divided into three responses: first change was observed within the $10 \mathrm{~km}$ buffer, the second within the continuum between $20-60 \mathrm{~km}$ buffers, and the last within the $70-80 \mathrm{~km}$ buffer zones. In the midstream region, all buffer zones showed a significant net gain in 2011-2012, indicating that the completion of the Santo Antônio dam had a significant impact on the water area. For the Santo Antônio dam, the loss intensity of 40-80 km buffer zones reached a peak in 2014-2015. The 10-30 km buffer zones didn't manifest significant loss intensity before and after the dam constructions. The $10 \mathrm{~km}$ and $50 \mathrm{~km}$ buffer zones showed higher gain intensities, while the $30 \mathrm{~km}$ and $80 \mathrm{~km}$ buffer zones had lower gain intensities in 
2011-2012. In the downstream region, only the buffer zone located $80 \mathrm{~km}$ from the Santo Antônio dam showed obvious net change (loss). Generally, the impacts of dam constructions on water area change were insignificant in the downstream region. The 70-80 km buffer zones had higher loss intensity in 2015-2016, which was similar to the upstream region. There was no obvious variation of gain intensity for the downstream in 2009-2017, as observed for the two other regions.

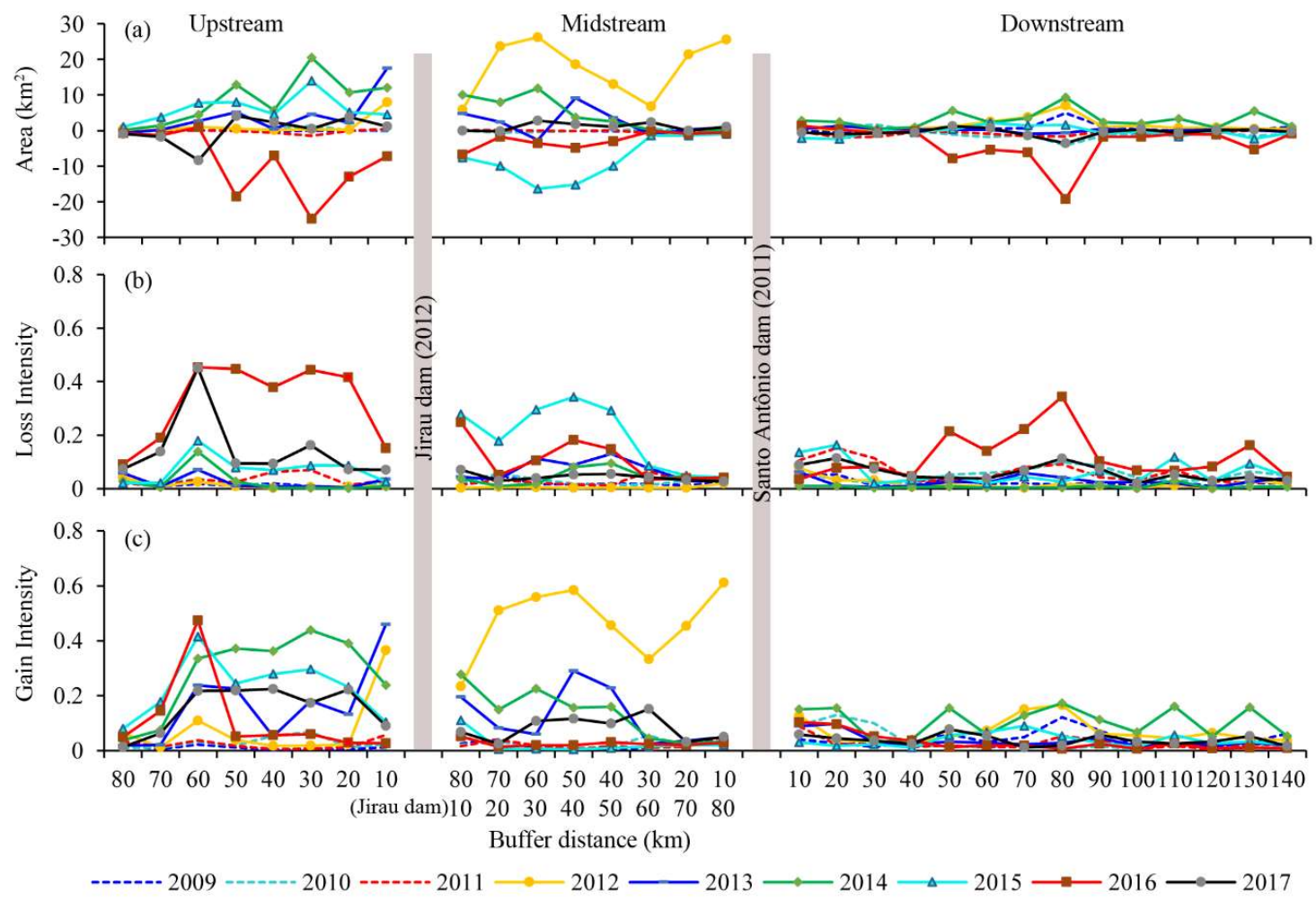

Figure 9. (a) Water area net change; (b) Loss intensity; (c) Gain intensity in different buffer zones from 2008 to 2017 (i.e., 2008-2009, 2009-2010, . . , 2016-2017. Only these years close to dam construction were shown in order to describe the impact of dam construction concisely).

\section{Discussion}

\subsection{The Uncertainty of Classification and Its Influence}

It is important to know how the classification uncertainties in the LULC data affect the analysis and the conclusions. The hypothetical error intensity at the category level for water gain and loss in each interval (i.e., year to year from 1985 to 2017) was computed to test a null hypothesis that the change intensities among all LULC categories are uniform [36,48]. A larger hypothetical error gives stronger evidence against this null hypothesis. The whole study area was taken as an example to illustrate the error analysis of LULC. Water gain commission/omission error intensities ranged from $0.71 \%$ to $86 \%$, and water loss commission/omission error intensities ranged from $0.06 \%$ to $74 \%$, both with the average $33 \%$ under the uniform change intensity hypothesis (Table S1). Thus, given these intervals with very low hypothetical error intensity, the conclusion that water change was dormant/active had weaker confidence. MapBiomas reported the overall and per-category classification accuracy for each year during the period of 1985-2017 at the Amazon biome level. The overall accuracy of the LULC classification was $94 \%$ at level 1 in each year. The producer's accuracy and user's accuracy of water ranged from $72 \%$ to $86 \%$ and $83 \%$ to $93 \%$ in 1985-2017, respectively (Table S4). Based on this accuracy assessment, there were 7 years (1985, 1991, 1995, 2001, 2006, 2008, and 2012) when the actual commission/omission error intensities were larger than hypothetical error intensity for water loss. There were 8 years $(1989,1995,1998,1999,2000,2003,2006$, and 2016) when the actual 
commission/omission error intensities were larger than hypothetical error intensity for water gain. These years had low confidence in the dormant/active conclusions. Thus, the conclusions about the pattern of water change, whether stable or not, across these time intervals in terms of gain and loss intensities should be taken with caution. These years did not influence the conclusion about the dam constructions on water resource change. For upstream, midstream, and downstream regions, low confidence also most occurred before 2011, similar to the whole study area, and only water loss showed low confidence in 2012 after the completion of the dams (Table S1).

\subsection{Planned Versus Observed Impacts of Dam Construction on Water Area}

The Jirau and Santo Antônio dams in the Madeira River have been extremely controversial [5]. Cella-Ribeiro et al. [9] concluded the two dams were less harmful to fish assemblage compared with vertical-axis turbine systems based on dams, and given the results were suggested for other hydroelectricity projects in the Amazon. Latrubesse et al. [2] found that the Madeira River was seriously affected by the two dams and represented the most vulnerable area in the entire Amazon basin. Thoroughly understanding how dam construction affects the spatial-temporal process of LULC would provide key knowledge for future hydropower development and for ecosystem health assessment. The original environmental impact assessment (EIA) predicted that the water area of the Santo Antônio and Jirau dams' reservoirs (corresponding to our upstream and midstream regions) would cover $529 \mathrm{~km}^{2}$. Our results showed that the lowest water area was $470.2 \mathrm{~km}^{2}$ in 2012 , and the largest water area was $626.3 \mathrm{~km}^{2}$ in 2014 (abnormally high precipitation year) over the period of post-dam construction. It seems that EIA provided a relatively reasonable assessment of how the water area would change as an effect of the dams. The newly flooded area of $424 \mathrm{~km}^{2}$ in the upstream and downstream was larger than EIA estimated (i.e., $308 \mathrm{~km}^{2}$ ). The proportion of permanent water coverage throughout 2012-2017 was relatively low, and one-third of the area was flooded only once after the dam was completed.

\subsection{Water Change Intensity and Component Among Different Regions}

Compared with traditional methods that subjectively divided study periods into two or several segments based on the dam construction date [7], intensity analysis quantified the land change area and intensity and checked the stationarity state at the interval, category, and transition levels every year. For example, upstream and midstream regions had fast dynamics in 2011-2017 and 2010-2017 intervals, and the downstream kept consistently slow in 2006-2015 at an interval level for LULC. Thus, the dam constructions immediately changed the LULC patterns of upstream and midstream regions. Both upstream and downstream regions reached the highest change intensity at the 2015-2016 interval, while midstream peaked at 2011-2012 in terms of LULC. The dam constructions had a more direct and intense impact on midstream, while more gradual influences on the upstream region and no direct impact on downstream. Intensity analysis provided much information about each category changes from category level analysis. This is very helpful for studies that concern about a particular category of LULCC. Water gain intensity was continuously active during 2011-2017 in the upstream, meaning that water area due to dam constructions experienced more intensive gain than the uniform overall change for a long period. However, it should be noted that the loss intensity became active with an increasing trend during 2014-2017, meaning the water area experienced more intensive loss than overall change after a few years of dam operation. The midstream showed a different pattern with the water gain intensity only activated in 2011-2014. The gain intensity was dormant, and the loss intensity was active in 2014-2016. This dynamic brought a significant decrease in the water area and high proportions of quantity change. This trend was also observed by Cochrane et al. [4]. One of the important reasons might be the two dams were designed as run-of-the-river hydropower stations [9], and they did not need to preserve large reservoirs. However, in our study, the water area was based on the LULC data from the low water period (August to November) because the selected Landsat images were from June 1 to October 31 each year. The impacts caused by the dams might be substantially underestimated [4]. 
The water gain size and intensity also provided more information about the LULC category's transition from transition level analysis. Forests were the main category replaced by water (area changed) before and after the construction of the dams in the three regions. Intensity analysis attracted more attention to ONVA and ONFNF after the dam constructions in the upstream and midstream, respectively. Thus, we need to pay more attention not only to these newly flooded forests but also to non-forest and bare lands. With the prolonged and frequent submersion of forests and farmlands, these areas might change to ONVA and be sensitive to the hydrological changes related to the dams. The change in their ecological functions deserves more attention.

Change components analysis enhanced the interpretation of the difference between a category and overall LULC in terms of area and intensity. Moreover, the overall component intensity was conducive to the comparisons among different regions and time intervals. The dams had different impacts on LULC change components and water change components. The exchange was the major change component of LULC during 1985-2017 without significant changes after the construction (2012). According to the change components of water, the proportions of quantity change significantly increased after the dams were completed (2012) and became the major change components in upstream and midstream. For the water category in the Amazon region, the main omission error occurred in the forest (ranged from 0.11 to 0.25 ), and the main commission error occurred in ONFNF (0.04-0.11) and forest (0.02-0.08). Misclassification in the LULC data can contribute to exchange. Some of the forests on the floodplain of the Madeira River grow in the water for several months each year, i.e., they are called flooded forests [5]. This ecosystem dynamic inevitably challenges the LULC classification of these targeted regions, a challenge considerably augmented, given the high inter-annual variability due to the amount of precipitation and water level. The largest exchange size in water before dam constructions occurred in different years for upstream, midstream, and downstream regions, meaning the classification error might play a limited role in the exchange. Although the proportion of exchange in change components decreased after the construction of dams, the average exchange area of water changed from $2.54 \mathrm{~km}^{2}$ to $25.3 \mathrm{~km}^{2}$ after the construction of the dams and the area reached $57.1 \mathrm{~km}^{2}$ in 2016-2017 in the upstream region. The construction of dams significantly increased the exchange area in the upstream and midstream regions and led to a more fragmented watershed in the river system [4]. This is all the more surprising, given that the intent of building two dams, rather than one, was said to be to avoid flooding in Bolivia. Why Jirau is not releasing more of this water, producing more energy, and reducing the flooded area needs an explanation from those who manage the energy sector.

\subsection{Distance Effects of Dam Construction on Water Area Change}

Generally, the influence of the construction of the dams on the observed variations in water area decreases with the increase in distances from the dam sites and gradually stabilizes at a certain distance- - a trend observed in previous studies [17]. The threshold strongly depends on the characteristics of topography and reservoirs systems and size. Jirau and Santo Antônio dams were the first to adopt the horizontal bulb turbines and run-of-the-river technology in the Amazon region, therefore operating without large reservoirs. Previous studies have mostly focused on reservoir-based dams [7,11,17], while the influences of horizontal bulb turbines have been less evaluated. According to our study, the $30 \mathrm{~km}$ and $60 \mathrm{~km}$ buffer zones in the upstream were more sensitive to the construction of the dam. This was because these two buffer zones included the confluences of São Lourenço River and Mutum-Paraná River with the Madeira River, where a large area of their mouths flooded after the completion of the dams (Figure 5). In midstream, the water area decreased from $10 \mathrm{~km}$ to $30 \mathrm{~km}$ and increased from $30 \mathrm{~km}$ to $60 \mathrm{~km}$ and decreased from 60 to $80 \mathrm{~km}$ in 2011-2012, but this trend disappeared in the following years. For downstream, only the $80 \mathrm{~km}$ buffer zone showed an obvious change. This change was from the nearby seasonal lake and not from the Madeira River. The two dams did not cause noteworthy water area change in the downstream region. This is as it was meant to be. What is less clear why are the two dams holding more water in their reservoirs and increasing flooded area when they are meant to let the river flow as naturally as possible and not hold water in 
storage. This may be due to the selection of horizontal bulb turbines, which could be considered in future hydropower constructions in the Amazon region.

\section{Conclusions}

In this study, intensity analysis and difference components were used to characterize the LULC during the period of 1985 to 2017, and the impacts on water area dynamics caused by the two run-of-the-river dam constructions along the Madeira River in the Brazilian Amazon were examined. Our results showed that LULC change intensities of upstream and midstream regions became consistently higher in the year before the completion of Jirau and Santo Antônio dams, respectively, but the dam constructions did not enhance LULC change intensities downstream in the first few years after the constructions. The LULC change components of upstream and downstream were not significantly impacted, while midstream showed a high proportion of exchange in the two years before the dams were built.

The construction of Santo Antônio and Jirau led to a large increase in newly flooded areas significantly greater than predicted by EIA in 2005 . However, only $18.5 \%$ of the newly flooded areas became permanent water throughout 2012-2017. The water gross gain intensity was different in three regions. In the upstream, it was observed an active steady-state of water gross gain intensity after the completion of the dams, while in the midstream, it only lasted for three years. The response of water change in downstream was not obvious, but the largest gross gain and loss both occurred after the completion of the dams. The dam constructions changed the major difference component from exchange to quantity in both upstream and midstream regions. The confluences with tributaries determined the susceptibility of water area change in different distances, especially in upstream. Forest was the largest flooded category in the three regions in the post-dam period, while the highest gain intensity all occurred in ONVA after dams were completed. ONVA and farmland were the second largest flooded categories in upstream and midstream, respectively. Overall, the intensity analysis and difference component provided more information about the water area change for assessing the impacts of two run-of-the-river dams in the Madeira River than previously used methods. This study provided a comprehensive framework to assess the impacts of dam construction on water area change based on time series of LULC data.

Supplementary Materials: The following figure (S1) and tables (S1, S2, S3, and S4) are available online at http://www.mdpi.com/2073-4441/12/7/1921/s1. Figure S1: Annual gross loss and gain areas of forest and farming from 1985 to 2017 in upstream, midstream, and downstream. (Note: left bar and right bar in each year interval are gross losses to other categories and gross gains from other categories, respectively. The gross losses and gains of ONFNF, construction land, and ONVA were not provided here because of their small area. Water was analyzed in Section 4.2 in more detail. ONFNF: other non-forest natural formation, ONVA: other non-vegetated areas), Table S1: Average annual gross gain and loss areas of each category in pre-dam and post-dam periods in upstream, midstream, and downstream $\left(\mathrm{km}^{2}\right)$, Table S2: Average relative annual gain and loss areas to the study area for each category in pre-dam and post-dam periods (\%), Table S3: Average annual net change of each category in upstream, midstream, and downstream before and after the construction of the dam $\left(\mathrm{km}^{2}\right)$, Table S4: Commission and omission error intensities for upstream, midstream, downstream, and study areas for each interval from 1985 to 2017 (\%).

Author Contributions: D.L. (Dengqiu Li): Conceptualization, Methodology, Software, Writing-Original Draft. D.L. (Dengsheng Lu): Conceptualization, Supervision, Writing-Review and Editing. E.M. and R.F.B.d.S.: Conceptualization, Writing-Review and Editing. All authors have read and agreed to the published version of the manuscript.

Funding: This research was funded by the National Science Foundation, of the United States, under the program for Innovations at the Nexus of Food, Energy, and Water Systems (INFEWS), grant number 1639115, and we thank the National Natural Science Foundation of China for supporting data process, grant number 41701490.

Acknowledgments: Thanks to the MapBiomas for providing Land Use Land Cover data. Thanks to the editor and two anonymous reviewers for their constructive comments and valuable suggestions.

Conflicts of Interest: The authors declare no conflict of interest. The funders had no role in the design of the study; in the collection, analyses, or interpretation of data; in the writing of the manuscript, or in the decision to publish the results. 


\section{References}

1. Júnior, J.L.S.; Tomasella, J.; Rodriguez, D.A. Impacts of future climatic and land cover changes on the hydrological regime of the Madeira River basin. Clim. Chang. 2015, 129, 117-129. [CrossRef]

2. Latrubesse, E.M.; Arima, E.Y.; Dunne, T.; Park, E.; Baker, V.R.; d'Horta, F.M.; Wight, C.; Wittmann, F.; Zuanon, J.; Baker, P.A.; et al. Damming the rivers of the Amazon basin. Nature 2017, 546, 363-369. [CrossRef] [PubMed]

3. Castello, L.; Macedo, M.N. Large-scale degradation of Amazonian freshwater ecosystems. Glob. Chang. Biol. 2016, 22, 990-1007. [CrossRef] [PubMed]

4. Cochrane, S.M.V.; Matricardi, E.A.T.; Numata, I.; Lefebvre, P.A. Landsat-based analysis of mega dam flooding impacts in the Amazon compared to associated environmental impact assessments: Upper Madeira river example 2006-2015. Remote Sens. Appl. Soc. Environ. 2017, 7, 1-8. [CrossRef]

5. Fearnside, P.M. Brazil's Madeira river dams: A setback for environmental policy in Amazonian development. Water Altern. 2014, 7, 154-167.

6. Fearnside, P.M. Impacts of Brazil's Madeira river dams: Unlearned lessons for hydroelectric development in Amazonia. Environ. Sci. Policy 2014, 38, 164-172. [CrossRef]

7. Jiang, X.D.; Lu, D.S.; Moran, E.; Calvi, M.F.; Dutra, L.V.; Li, G.Y. Examining impacts of the Belo Monte hydroelectric dam construction on land-cover changes using multitemporal Landsat imagery. Appl. Geogr. 2018, 97, 35-47. [CrossRef]

8. Pickens, A.H.; Hansen, M.C.; Hancher, M.; Stehman, S.V.; Tyukavina, A.; Potapov, P.; Marroquin, B.; Sherani, Z. Mapping and sampling to characterize global inland water dynamics from 1999 to 2018 with full Landsat time-series. Remote Sens. Environ. 2020, 243, 111792. [CrossRef]

9. Cella-Ribeiro, A.; Doria, C.; Dutka-Gianelli, J.; Alves, H.; Torrente-Vilara, G. Temporal fish community responses to two cascade run-of-river dams in the Madeira River, Amazon basin: Fish responses to Amazon run-of-river dams. Ecohydrology 2017, 10, e1889. [CrossRef]

10. Fearnside, P.M. Decision-making on Amazon dams: Politics trumps uncertainty in the Madeira River sediments controversy. Water Altern. 2013, 6, 313-325.

11. Pracheil, B.M.; Derolph, C.R.; Schramm, M.P.; Bevelhimer, M.S. A fish-eye view of riverine hydropower systems: The current understanding of the biological response to turbine passage. Rev. Fish Biol. Fish. 2016, 26, 153-167. [CrossRef]

12. Gain, A.K.; Giupponi, C. Impact of the Farakka Dam on Thresholds of the Hydrologic Flow Regime in the Lower Ganges River Basin (Bangladesh). Water 2014, 6, 2501-2518. [CrossRef]

13. Pal, S. Impact of water diversion on hydrological regime of Atreyee River of Indo-Bangladesh. Int. J. River Basin Manag. 2016, 14, 459-475. [CrossRef]

14. Hecht, J.S.; Lacombe, G.; Arias, M.E.; Dang, T.D.; Piman, T. Hydropower dams of the Mekong River basin: A review of their hydrological impacts. J. Hydrol. 2019, 568, 285-300. [CrossRef]

15. Piman, T.; Lennaerts, T.; Southalack, P. Assessment of hydrological changes in the lower Mekong Basin from Basin-Wide development scenarios. Hydrol. Proces. 2013, 27, 2115-2125. [CrossRef]

16. Wang, J.; Sheng, Y.; Wada, Y. Little impact of the Three Gorges Dam on recent decadal lake decline across China's Yangtze Plain. Water Resour. Res. 2017, 53, 3854-3877. [CrossRef]

17. Zhao, Q.H.; Liu, S.L.; Deng, L.; Dong, S.K.; Yang, Z.F.; Liu, Q. Determining the influencing distance of dam construction and reservoir impoundment on land use: A case study of Manwan Dam, Lancang River. Ecol. Eng. 2013, 53, 235-242. [CrossRef]

18. Talukdar, S.; Pal, S. Impact of dam on inundation regime of flood plain wetland of Punarbhaba river basin of Barind tract of Indo-Bangladesh. Int. Soil Water Conserv. Res. 2017, 5, 109-121. [CrossRef]

19. Al-Madhhachi, A.T.; Rahi, K.A.; Leabi, W.K. Hydrological impact of Ilisu Dam on Mosul Dam; the River Tigris. Geosciences 2020, 10, 120. [CrossRef]

20. Yihdego, Y.; Khalil, A.; Salem, H.S. Nile River's basin dispute: Perspectives of the Grand Ethiopian Renaissance Dam (GERD). Glob. J. Hum. Soc. Sci. 2017, 17, 1-21.

21. Zhang, F.; Tashpolat, T.; Kung, H.; Ding, J.L. The change of land use/cover and characteristics of landscape pattern in arid areas oasis: An application in Jinghe, Xinjiang. Geo-spatial Inf. Sci. 2010, 13, 174-185. [CrossRef]

22. Yihdego, Y.; Webb, J.A. An empirical water budget model as a tool to identify the impact of land-use change in stream flow in southeastern Australia. Water Resour. Manag. 2013, 27, 4941-4958. [CrossRef] 
23. Gao, P.; Mu, X.M.; Wang, F.; Li, R. Changes in stream flow and sediment discharge and the response to human activities in the middle reaches of the Yellow River. Hydrol. Earth Syst. Sci. 2011, 15, 1-10. [CrossRef]

24. Lobo, G.D.S.; Wittmann, F.; Piedade, M.T.F. Response of black-water floodplain (igapó) forests to flood pulse regulation in a dammed Amazonian river. For. Ecol. Manag. 2019, 434, 110-118. [CrossRef]

25. Lyon, S.W.; King, K.; Polpanich, O.; Lacombe, G. Assessing hydrologic changes across the Lower Mekong Basin. J. Hydrol. Reg. Stud. 2017, 12, 303-314. [CrossRef]

26. Shrestha, B.; Cochrane, T.A.; Caruso, B.S.; Arias, M.E. Land use change uncertainty on streamflow and sediment projections in areas undergoing rapid development: A case study in the Mekong Basin. Land Degrad. Dev. 2018, 29, 835-848. [CrossRef]

27. Talukdar, S.; Pal, S. Effects of damming on the hydrological regime of Punarbhaba river basin wetlands. Ecol. Eng. 2019, 135, 61-74. [CrossRef]

28. Li, D.Q.; Lu, D.S.; Li, N.; Wu, M.; Shao, X.X. Quantifying annual land-cover change and vegetation greenness variation in a coastal ecosystem using dense time-series Landsat data. Gisci. Remote Sens. 2019, 56, 769-793. [CrossRef]

29. Li, D.Q.; Lu, D.S.; Wu, M.; Shao, X.X.; Wei, J.H. Examining land cover and greenness dynamics in Hangzhou Bay in 1985-2016 using Landsat time-series data. Remote Sens. 2018, 10, 32. [CrossRef]

30. Peñas, F.J.; Barquín, J. Assessment of large-scale patterns of hydrological alteration caused by dams. J. Hydrol. 2019, 572, 706-718. [CrossRef]

31. Bonnema, M.; Hossain, F. Inferring reservoir operating patterns across the Mekong Basin using only space observations. Water Resour. Res. 2017, 53, 3791-3810. [CrossRef]

32. Aldwaik, S.Z.; Pontius, R.G., Jr. Intensity analysis to unify measurements of size and stationarity of land changes by interval, category, and transition. Landsc. Urban Plan. 2012, 106, 103-114. [CrossRef]

33. Chen, G.; Powers, R.P.; de Carvalho, L.M.T.; Mora, B. Spatiotemporal patterns of tropical deforestation and forest degradation in response to the operation of the Tucuruí hydroelectric dam in the Amazon basin. Appl. Geogr. 2015, 63, 1-8. [CrossRef]

34. Huang, J.L.; Pontius, R.G., Jr.; Li, Q.S.; Zhang, Y.J. Use of intensity analysis to link patterns with processes of land change from 1986 to 2007 in a coastal watershed of southeast China. Appl. Geogr. 2012, 34, 371-384. [CrossRef]

35. Huang, B.Q.; Huang, J.L.; Pontius, R.G., Jr.; Tu, Z.S. Comparison of Intensity Analysis and the land use dynamic degrees to measure land changes outside versus inside the coastal zone of Longhai, China. Ecol. Indic. 2018, 89, 336-347. [CrossRef]

36. Pontius, R.G., Jr.; Gao, Y.; Giner, N.M.; Kohyama, T.; Osaki, M.; Hirose, K. Design and interpretation of intensity analysis illustrated by land change in Central Kalimantan, Indonesia. Land 2013, 2, 351-369. [CrossRef]

37. Romero-Ruiz, M.H.; Flantua, S.G.A.; Tansey, K.; Berrio, J.C. Landscape transformations in savannas of northern South America: Land use/cover changes since 1987 in the Llanos Orientales of Colombia. Appl. Geogr. 2012, 32, 766-776. [CrossRef]

38. Zhou, P.; Huang, J.L.; Pontius, R.G., Jr.; Hong, H.S. Land classification and change intensity analysis in a coastal Watershed of Southeast China. Sensors 2014, 14, 11640-11658. [CrossRef]

39. Pontius, R.G., Jr.; Santacruz, A. Quantity, exchange, and shift components of difference in a square contingency table. Int. J. Remote Sens. 2014, 35, 7543-7554. [CrossRef]

40. Pontius, R.G., Jr. Component intensities to relate difference by category with difference overall. Int. J. Appl. Earth Obs. Geoinf. 2019, 77, 94-99. [CrossRef]

41. Quan, B.; Ren, H.G.; Pontius, R.G., Jr.; Liu, P.L. Quantifying spatiotemporal patterns concerning land change in Changsha, China. Landsc. Ecol. Eng. 2018, 14, 257-267. [CrossRef]

42. Shafizadeh-Moghadam, H.; Minaei, M.; Feng, Y.J.; Pontius, R.G., Jr. GlobeLand30 maps show four times larger gross than net land change from 2000 to 2010 in Asia. Int. J. Appl. Earth Obs. Geoinf. 2019, 78, 240-248. [CrossRef]

43. De Souza, C.A.; Vieira, L.C.G.; Legendre, P.; de Carvalho, P.; Velho, L.F.M.; Beisner, B. Damming interacts with the flood pulse to alter zooplankton communities in an Amazonian river. Freshw. Biol. 2019, 64, 1040-1053. [CrossRef]

44. Bastos, W.R.; de Almeida, R.; Dórea, J.G.; Barbosa, A.C. Annual flooding and fish-mercury bioaccumulation in the environmentally impacted Rio Madeira (Amazon). Ecotoxicology 2007, 16, 341-346. [CrossRef] 
45. Melo, T.; Torrente-Vilara, G.; Röpke, C.P. Flipped reduce tarianism: A vegan fish subordinated to carnivory by suppression of the flooded forest in the Amazon. For. Ecol. Manag. 2019, 435, 138-143. [CrossRef]

46. Wang, H.R.; Chen, Y.C.; Liu, Z.W.; Zhu, D.J. Effects of the "Run-of-River" hydro scheme on macroinvertebrate communities and habitat conditions in a Mountain River of Northeastern China. Water 2016, 8, 31. [CrossRef]

47. Olofsson, P.; Foody, G.M.; Herold, M.; Stehman, S.V.; Woodcock, C.E.; Wulder, M.A. Good practices for estimating area and assessing accuracy of land change. Remote Sens. Environ. 2014, 148, 42-57. [CrossRef]

48. Aldwaik, S.Z.; Pontius, R.G., Jr. Map errors that could account for deviations from a uniform intensity of land change. Int. J. Geogr. Inf. Sci. 2013, 27, 1717-1739. [CrossRef]

(C) 2020 by the authors. Licensee MDPI, Basel, Switzerland. This article is an open access article distributed under the terms and conditions of the Creative Commons Attribution (CC BY) license (http://creativecommons.org/licenses/by/4.0/). 